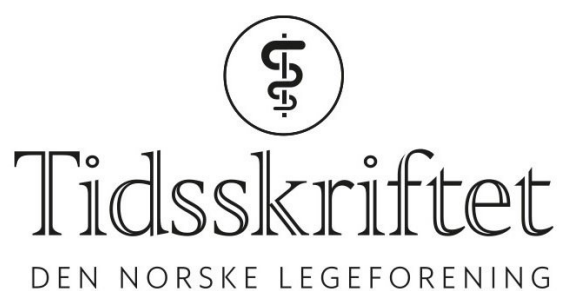

DEN NORSKE LEGEFORENING

\title{
Det bør hete evidensbasert medisin
}

SPRÅKSPALTEN

PETTER GJERSVIK

E-post: petter.gjersvik@medisin.uio.no

Petter Gjersvik er professor ved Institutt for klinisk medisin, Universitetet i Oslo, medisinsk redaktør i Tidsskriftet og medlem av Gruppe for norsk medisinsk fagspråk.

Kunnskapsbasert medisin er en lite presis og lite hensiktsmessig oversettelse av evidencebased medicine.

Uttrykket evidence-based medicine ble lansert i 1991 som en ny tilnærming til medisinsk opplæring og kliniske beslutninger $(1,2)$. Begrepet innebærer at vurderinger i klinisk praksis bør være basert på en systematisk innsamling av god dokumentasjon av effekten av en intervensjon, helst fra randomiserte kontrollerte studier og metaanalyser. Evidence-based medicine har fått stor betydning for klinisk praksis, medisinsk forskning og helsepolitiske vurderinger i alle land, også Norge, og det britiske tidsskriftet BMJ omtalte introduksjonen av evidence-based medicine som en av de 15 viktigste milepælene i medisinens historie etter 1840 (3).

Uttrykket kunnskapsbasert medisin ble i 1995 lansert som norsk oversettelse av evidence-based medicine (4). Valget ble bl.a. begrunnet med at det engelske uttrykket var vanskelig å oversette direkte, og at kunnskapsbasert medisin var det «som best ivaretar hovedintensjonen i det som ligger bak begrepet» (5). Denne oversettelsen ble tatt i bruk av mange lærebokforfattere og fagfolk. Likevel synes det som om uttrykket ikke helt har villet etablere seg blant klinikere og i allmennheten.

\section{Språklige avveininger}

Betydningen av evidence varierer etter hvilken sammenheng ordet brukes i. I engelskspråklig rettspleie og jus brukes det for det vi på norsk vil betegne som bevis og bevismateriale (6). I engelskspråklig dagligtale, derimot, brukes det mindre spesifikt enn bevis på norsk, dvs. tilsvarende støtte, belegg og dokumentasjon på norsk (6). Evidence og proof er altså ikke helt synonyme begreper. Klinisk praksis og medisinsk vitenskap er ikke basert på bevis, men på erfaring, dokumentasjon og statistikk. Evidence på engelsk kan derfor ikke uten videre oppfattes som bevis på norsk.

Så hvorfor ikke oversette evidence med evidens? Evidens er et norsk ord, basert på évidence på fransk fra evidentia på latin, og har vært i bruk helt fra midten av 18oo-tallet (7). Bruken har vært $\varnothing$ kende etter 1990 (7), noe som kan skyldes økende innflytelse fra engelsk på norsk språkpraksis. Det Norske Akademis ordbok definerer evidens bl.a. som «det å være dokumenterbar» (8). Nærmere betydningen av ordet evidence i uttrykket evidence-based medicine er det etter mitt skjønn vanskelig å komme: evidensbasert medisin er medisin basert på det som er dokumenterbart. 


\section{Et nytt og dermed annet begrep}

Valget av uttrykket kunnskapsbasert medisin ble som nevnt begrunnet med at «kunnskap er det norske ordet som best ivaretar hovedintensjonen i det som ligger bak begrepet» (5). To idéhistorikere skrev i Tidsskriftets språkspalte i 2018 at dette valget også hadde en erkjennelsesmessig side, og at man «løsrev» seg fra «forbindelsene til 'bevis' og 'entydige fakta' og dermed fra de positivistiske konnotasjonene som knytter seg til det engelske uttrykket» (9).

Det er vanskelig å være uenig i at medisinsk praksis skal være kunnskapsbasert. Evidensbasert medisin er noe annet

Uttrykket kunnskapsbasert medisin oppfattes altså som noe annet og mer enn evidence-based medicine. Oversettelsen kunnskapsbasert medisin blir derfor lite presis og tolkes som et fors $\emptyset \mathrm{k}$ på å forsvare seg mot kritikk om en positivistisk holdning til medisinsk forskning og klinisk praksis.

Det er vanskelig å være uenig i at medisinsk praksis skal være kunnskapsbasert. Evidensbasert medisin er noe annet: en tilnærming til klinisk praksis basert på en systematisk innsamling av god dokumentasjon, helst (men ikke bare) fra randomiserte kontrollerte studier og metaanalyser.

\section{Uttrykket har ikke helt slått an}

Gode oversettelser kjennetegnes av at de blir tatt i bruk. Et søk på Nasjonalbibliotekets søketjeneste over ordbruk i bøker viser en svakt økende bruksfrekvens for kunnskapsbasert medisin utover 1990- og 200o-tallet (10). Bruksfrekvensen av evidensbasert medisin økte mer, passerte bruksfrekvensen for kunnskapsbasert medisin i 2000 og var mer enn dobbelt så stor som frekvensen for kunnskapsbasert medisin i 2010. Uttrykket kunnskapsbasert medisin synes altså å tape terreng til fordel for evidensbasert medisin.

\section{Konklusjon}

Etter mitt syn er evidensbasert medisin en mer egnet oversettelse av evidence-based medicine enn kunnskapsbasert medisin. Evidensbasert medisin synes allerede å være den mest foretrukne oversettelsen i norsk språkpraksis.

\section{LITTERATUR:}

1. Guyatt GH. Evidence-based medicine. ACP J Club 1991; 114: A-16.

2. Guyatt G, Cairns J, Churchill D et al. Evidence-based medicine. A new approach to teaching the practice of medicine. JAMA 1992; 268: 2420-5. [PubMed][CrossRef]

3. BMJ. Medical milestones. https://www.bmj.com/content/medical-milestones Lest 12.5.2019.

4. Nylenna M. Kunnskapsbasert medisin eller politiske alternativer? Arbeiderpartiets leder anbefaler akupunktur og homøopati. Tidsskr Nor Laegeforen 1995; 115: 811-2. [PubMed]

5. Nylenna M. Kunnskapsbasert medisin. Tidsskr Nor Legeforen 1996; 116:1817.

6. Stor engelsk ordbok. Evidence. https://www.ordnett.no/search?languageen\&phraseevidence Lest 12.5.2019.

7. Nasjonalbiblioteket. 2015. NB N-gram. Evidens.

https://www.nb.no/sp_tjenester/beta/ngram_1/\#ngram/query?termsevidens\&lang-

all\&case_sens=o\&freqrel\&corpusbok Lest 12.5.2019.

8. Det Norske Akademis ordbok. Evidens. https://www.naob.no/ordbok/evidens Lest 12.5.2019.

9. Bondevik H, Engebretsen E. Kunnskapsbasert medisin på norsk. Tidsskr Nor Legeforen 2018; 138. doi: 10.4045/tidsskr.18.0524. [CrossRef] 
10. Nasjonalbiblioteket. 2015. NB N-gram. Kunnskapsbasert medisin, evidensbasert medisin. https://www.nb.no/sp_tjenester/beta/ngram_1/\#ngram/query?terms-

kunnskapsbasert+medisin $\% 2 \mathrm{C}+$ evidensbasert+medisin\&langall\&case_sens=o\&freqrel\&corpusbok Lest 13.4.2019.

Publisert: 7. oktober 2019. Tidsskr Nor Legeforen. DOI: 10.4045/tidsskr.19.0348

(C) Tidsskrift for Den norske legeforening 2020. Lastet ned fra tidsskriftet.no 